The Geneva Papers on Risk and Insurance, 23 (No. 87, April 1998), 169-177

\title{
Insuring the Uninsurable? The Appeal of the Circumstances Clause
}

An investigation into the compatibility of claims made policies with society's demand for adequate liability insurance

by Geert Schoorens* and Caroline Van Schoubroeck**

\section{Introduction}

Liability insurance provides coverage for liability incurred by the insured within the period of coverage. In many cases, it is obvious whether liability was incurred within or outside this period. In motor vehicle liability for example, negligent driving, collision and claim by the victim generally ${ }^{1}$ take place within a period of hours, days or weeks. Other liabilities on the other hand take much more time to develop. Therefore they are called "long tail" liabilities. Mostly quoted in this category are liabilities for defective products, environmental damage, malpractice and E\&O. From the initial incident leading to exposure to damage, over the first signs of such damage until the blatent manifestation of loss in all its aspects, to the filing of the claim by the victim and the sentence of the court, many years or even decades can elapse. Because of this, assigning a specific date to the moment when liability is established becomes difficult and all the more crucial. For it is quite possible that during this process of establishing liability, the insured has switched insurers once or even more, each of which has given coverage during only a part of this development process. Which insurer will in that case be liable to indemnify the victim ${ }^{2}$ ?

\footnotetext{
* Member of the Centre for Risk and Insurance Studies, Catholic University K.U.Leuven (Belgium).

** Post-doctoral Fellow Fund of Scientific Research, Flanders (Belgium); member of the Center for Risk and Insurance Studies, Catholic University K.U.Leuven (Belgium).

${ }^{1}$ In some cases, even in motor vehicle liability, it still might take a while before damage is fully revealed. A well known example are complaints of whip-lash.

2 To paint the full picture, it should be added that different moments in the development of liability can be important, depending on the legal consequences one wants to link to this moment. The obligation to notify the insurer of the accident for example can be triggered before or after the moment that is decisive in the selection of the insurer who has to indemnify. In other words in insurance law the insured "case" has more than one meaning.
} 


\section{Three main models triggering the insurer's obligation to indemnify}

It is widely accepted that three main models exist to specify this moment in time triggering the insurer's obligation to indemnify. The so called insurance on "act committed" basis provides coverage whenever the insured's liability can be linked to an act or event that took place during the insurance contract term. It is irrelevant when the loss occurred or the claim was filed. Thus an "act committed" insurance contains coverage for a substantial run off period during which losses or claims can arise that are linked to acts committed in the contract period.

In a liability insurance on a "loss occurrence" basis, the obligation to indemnify is triggered only when the damage giving rise to liability occurred during the term of this contract. There is coverage even when the cause of this loss is found in an act or event that took place before the conclusion of the policy (coverage for a run in period) or when the eventual claim is only filed after the expiration of the policy (coverage for a run off period).

Finally, in a "claims made" model the insurer provides coverage only if the eventual claim is filed by the victim during the contract period. Since such a claim forms the tailpiece of the liability process, claims made insurance in principle does not give coverage for any run off period. The run in coverage however is substantial, since it does not matter when the act or loss that gave rise to this claim actually occurred.

\section{Long tail risks and the social function of liability insurance}

Apart from being an economic service, private liability insurance has an important social function ${ }^{3}$. It not only protects those insured against fate or imprudent behaviour in daily private and professional life, but it also protects the victims against insolvent liable persons. It thus provides stability and peace of mind to society. Moreover, it allows citizens to engage in entrepreneurial ventures which would have been unattainable without the benefit of insurance. It thus plays an important role in the promotion of social welfare. This appeal to the insurance industry by society creates certain expectations. One of which is that insurance and liability "match", i.e. that insurance effectively provides coverage when liability is incurred.

From this point of view "act committed"-policies with unlimited run off coverage, do not pose any problem at all. This type of policy undoubtedly meets the insured's legitimate expectations. He will be covered for any possible future claims resulting from an act committed within the contract period ${ }^{4}$. Policies based on one of the two other triggers are

${ }^{3}$ See PICARD, M. and BESSON, A., Les assurances terrestres, I, Paris, Librairie Générale de Droit et de Jurisprudence, 1982, p. 521, $\mathrm{n}^{\circ} 352$ : “(...) l'assurance des responsabilités est une véritable nécessité individuelle et sociale: (...) l'assurance (...) laisse (l'homme) le goût de l'action et de l'initiative, en même temps qu'elle donne aux victimes une garantie efficace de réparation"; LAMBERT-FAIVRE, Y., "Le sinistre en assurances de responsabilité des victimes", Revue Générale des Assurances Terrestres (Fr.), 1987, 206-207: “Aujourd'hui, (...) (la garantie de la créance d'indemnisation de la victime) est devenue la finalité même des assurances de responsabilité".

${ }^{4}$ Certainly when the time-lapse between the act and the claim is rather long, act committed policies also are said to have some drawbacks. First, it will be difficult to locate exactly at which moment in the past the act was committed, and thus which insurer must indemnify. Second, the insured will be faced with limits to the amount of coverage that are no longer adapted to today's liability risks. With regard to this last drawback it can be said that the insured will equally likely be faced with more exclusions in the policy today than at the time the act was committed. Moreover, the drawback of inadequate coverage ceilings can be overcome by giving each time retroactive effect to the newly negotiated higher amounts of coverage. 
in this respect more troublesome. The insured will not receive coverage for damage sustained or claims filed after the expiration of the policy, though the events at the basis of this damage or claim have in fact taken place during the insurance period. These models impair the insured's pre-legal intuition as to the existence of coverage and therefore create legitimate concern with the legislator or the judiciary ${ }^{5}$.

Equally troublesome in this respect is the tendency in liability insurance to confine coverage of claims filed after the expiration of the policy to a specified period of time. Liability of the insured and likewise indirectly the obligation of the insurer to indemnify, already are limited by legal limitation periods. Since these periods tend to be quite long, can start to run quite late, and are subject to suspension and interruption, this seems inadequate. Many regulations and insurance conditions, especially in insurance for liabilities in connection with entrepreneurial activity and liberal professions, provide more far-reaching limitations. Again, in these cases, liability and insurance no longer match perfectly, the insured and the victim being left with their damages without the reassuring backup of a solvent insurer.

As stated previously many European policymakers face with great anxiety this growing loss of adequate liability insurance coverage. Thus, Spain and Belgium have enacted specific legal provisions for this problem. France has a very stringent case law stated by the Cour de Cassation. Other countries take less initiatives, but there the insurance industry has a more-developed tradition of self-regulation with concern for insured's interests ${ }^{6}$. Thus the Dutch and German insurance industry have developed standard policy conditions. It remains unclear however to what extent they are applied in practice by most insurance companies. The English standard market practice is less structured.

\section{Uninsurability of long tail risks}

Since the insurance sector will need very good reasons to convince the Argus-eyed authorities to tolerate such confinements in coverage, it is of utmost importance to clearly formulate them. Generally, these arguments are put in terms of "uninsurability". Providing coverage exclusively based on "act committed" and/or for run off periods which are only limited by legal limitation periods, simply is technically not feasible. The assertion however that the insurer would otherwise have to keep records of all his contracts without ever being able to definitely close a file, does not hold water. Extra accomodation to store archives or buying extra storage capacity for the data system does indeed cost money. That these cost-considerations amount to insurability problems however is a false argument. The insurer can simply adjust his calculations beforehand and raise the premium until

${ }_{5}$ The French Cour de Cassation even imposes the act committed model with unlimited run off coverage to all liability insurances. Needless to say this has landed relations between judiciary and insurance sector in a deadlock. The Cour the Cassation has recently even condemned an insurer twice for "abuse of appeal" ("pourvoi abusif") against judgments confirming this case law: see COURTIEU, G., "Les pourvois abusifs en droit des assurances", Responsabilité civile et assurances, February 1997, 4-5.

${ }^{6}$ This at first sight very noble and altruistic attitude of insurers is in fact for a good deal inspired by a well-considered self-interest. By accomodating (partly) insured's interests, insurers try and avoid legislature or judicature of imposing measures on which they have less control. 
these costs are included in the price of the product. It therefore seems hard to sustain that adequacy of liability coverage should be sacrificed for the sake of mere cost-control.

Another group of arguments is more convincing. The longer the time period within which the insurer can be tackled to pay compensation, the greater the odds are that in the meantime the risk itself ${ }^{7}$, the general knowledge about the risk ${ }^{8}$, the laws on liability and insurance $^{9}$, or the claims consciousness in society ${ }^{10}$ are subject to change. This way one of the very foundations of sound insurance business is crumbling, namely the approximative anticipation of future claims through the use of reliable statistical data. Contrary to the previous problems concerning closure of files, insurers are here faced with claims which they could not have foreseen at the time the policy was concluded. Insurers could never have calculated these changes in the premium, because "the rules of the game are changed (only) halfway through the match" 11 . Economists have analysed these kinds of problems in terms of "uncertainty" instead of "risk" 12 . More recently they were narrowed down through the concepts of risk with ambiguous probability and/or uncertain loss 13.

It is important to note that the argument thus only holds for the so-called "long tail risks" where liability on average takes much more time to develop. This means e.g. that the larger part of liability risks of the general public lack any basis justifying such limitations to coverage. Since some insurers tend to cover accidental and gradual/progressive environmental damage in two separate sections or even policies, one could argue that such accidental damage cannot be covered on a claims made basis.

\section{Present day insurance market tendencies: a fair balance of interests ?}

The fear of having to insure the uninsurable, pushes insurers towards the choice for a moment in time that triggers their obligation to indemnify only later in the process of liability. Hence the strong tendency to shift from "act committed" to "loss occurrence" or even "claims made" policies. This way insurers shorten or even eliminate the time period

\footnotetext{
${ }^{7}$ For example, the magnitude of possible loss will rise sharply when, after the conclusion of the liability insurance contract, a tree nursery is set up next to the insured with a defective oil cistern.

${ }^{8}$ With the lapse of time for example the possibie harmful consequences of metal fatigue may turn out to be much greater than originally predicted at the time of the contract. The same goes for recent discussions concerning electro magnetic fields.

${ }^{9}$ The legislator may replace a liability based on fault retroactively by a no-fault liability; the courts may adjust their interpretation of a liability standard in a way that increases insurer's obligation to indemnify: e.g. for a more and more patient-oriented interpretation of liability standards in medical malpractice cases, in the United States, France and Belgium, see VANSWEEVELT, T., De civielrechtelijke aansprakelijkheid van de geneesheer en het ziekenhuis, Antwerp, Maklu, 1992, p. 831$833,11^{\circ} 1361-131363$, and references.

${ }^{10}$ Patients today are for example less reluctant than before to start legal proceedings for medical malpractice; see e.g., for Holland, BOLT, A.T. and SPIER, J., "De uitdijende reikwijdte van de aansprakelijkheid uit onrechtmatige daad - Preadvies Nederlandse Juristenvereniging 1996", Zwolle, Tjeenk Willink, 1996, p. 20.

"FAURE, M.G., "The Limits to Insurability from a Law and Economics Perspective", Geneva Papers on Risk and Insurance, 1995, (454), 455.

${ }^{12}$ See e.g. KNIGHT, F.H., Risk, Uncertainty and Profit, Boston, Houghton-Mifflin, 1921; GOLLIER, Ch., "Le risque de développement est-il assurable?", Risques, 1994, 49.

${ }^{13}$ GOLLIER, Ch., "About the Insurability of Catastrophic Risks", Geneva Papers on Risk and Insurance, 1997, (177), 181-182; KUNREUTHER, H., HOGARTH, R. and MESZAROS, J., "Insurer Ambiguity and Market Failure", Journal of Risk and Uncertainty, 1993, 71-87, and references.
} 
between the trigger and the eventual claim, i.e. the period within which the rules of the game are submitted to possible changes. Moreover in "act committed" and "loss occurrence" policies the remaining run off period is further shortened by straight measures that limit this period to $\mathrm{x}$ months or years. It should be stated that for equity reasons many insurers soften the harshness of "claims made" policies by providing a so called "extended reporting period", i.e. a short period after the end of the policy within which claims can still be filed successfully.

From an insured's point of view these modifications to liability coverage leave a lot to be desired. Not only does he lose coverage for any claims filed after the limited run off period. The shift towards "loss occurrence" and "claims made" policies also deprives him from coverage for acts committed during the insurance contract but which lead to loss or claims only after the end of this contract.

One could say the insured has only himself to blame. If he had simply taken out a similar new insurance, then he would have been covered for the latter losses or claims. First of all, there is no reason to blame the insured who terminates the insurance contract because he discontinued his risky activities (e.g. retirement, death, merger, acquisition) ${ }^{14}$. But even in the situation of two succeeding insurance contracts an important gap still remains. The second insurer will not provide coverage for losses or claims during the contract period related to events which were known by the insured at the time of the conclusion of the second contract. The insured has a duty to disclose these events. If he has done so, the insurer will most likely exclude them from coverage. If he has concealed them, the insurer will mosî likely refuse coverage.

By shifting towards a loss occurrence or claims made policy, what happens in fact is that the insurer artificially chooses as the moment of realisation of the risk, a moment in time much later than the genuine moment of realisation of risk, namely the moment from when the insured realises something is wrong. This way the insurer succeeds in avoiding the problem of insurability linked with extremely long run off periods. But in fact this does nothing more than shifting the problem back to the period before the new trigger. There, the problem of uninsurability resurrects in another form, as a problem not so much for the insurer as for the insured. Due to the much longer run in period, the insured risks to know before the insurer is legally obliged to indemnify. Any change in insurance between these two moments, creates problems of alea and disclosure of known facts, which will be born by the insured. In essence, the insurer's risk not to know is replaced by the insured's risk to know.

The only way of avoiding this problem is to remain always with the same insurer. However one does not always have this decision in hand oneself (e.g. the insurer can terminate the contract). Moreover, this approach is not in line with the aim of a workable competitive insurance market. Therefore techniques should be developed to avoid the drawbacks of the loss occurrence and the claims made policies, in other words to fill the

${ }^{14}$ Insurers acknowledge for this specific situation the unfairness of loss occurrence and claims made policies, and/or limited run off periods. Retirees, the estate or the new legal entity are generally allowed to buy extra coverage with their last insurer on an "act committed" basis for any liability that can be incurred in the future for acts related to the ended business. This extra coverage however is regularly also limited in time (e.g. a period of $3,5,10$ years). 
gaps in coverage, without bringing in once again the problems of uninsurability. The principal technique that seems to succeed most in reconciling these opposing interests is the so-called "circumstances clause". In many European countries it can be found in some form or another as an accessory to the main trigger.

\section{The circumstances clause}

The term "circumstances" refers to events that occurred during the contract term and may be presumed in all reasonableness to give rise in the future to damage or a claim. When a "circumstances clause" is inserted in the policy conditions, the insured will receive coverage for liabilities these events might eventually give rise to, under the condition that he notifies his insurer of these circumstances before the end of the contract.

Coverage based on the circumstances clause can be assigned regardless of the main trigger that is being used. It has been included in liability insurances where the obligation of the insurer to indemnify is triggered by the occurrence of the loss and the claim (Belgium ${ }^{15}$ ) or by the filing of the claim (Netherlands ${ }^{16}$, UK ${ }^{17}$, USA ${ }^{18}$, Australia ${ }^{19}$ ). In both cases the clause certainly adds to coverage, since these circumstances generally have not yet led to damage or claims before the end of the contract. Despite the fact that to our knowledge the clause cannot be found as such in market practice, it is conceivable in a policy with "loss occurrence" coverage. It is even conceivable in an "act committed" policy. It is true that all "circumstances" are at the same time events and as such already covered by the main "act committed" trigger. The circumstances clause though can still provide an addition to coverage, insofar as it generally offers a longer or even unlimited run off coverage.

In the hypothesis of two succeeding liability insurance contracts, the insertion of a circumstances clause in the first contract seems to be a solution capable of closing the above mentioned gaps in coverage, without vitiating at the same time the prerequisite of insurability. At the end of the first contract, the insured will notify the first insurer of all circumstances known to him. Consequently, he will retain coverage under the first policy. All the other events which cannot be qualified as "circumstances" will be covered under the second policy. These (f)acts form part of the unknown past of the insured and are as such insurable by the succeeding insurer.

The technical feasability of this construct is not put at risk again. The first insurer is perfectly capable of making a global loss reserve on the basis of the list of circumstances. First, the risk of future claims can be assessed more easily since it is linked to a limited list of known and disclosed circumstances. Second and more important, the risk of being held to pay damages for unforeseeable risks because "the rules were changed half way through

${ }^{15}$ Article 78, $\$ 2$ of the Belgian Insurance Contracts Act.

${ }^{16}$ Article 21 of the Dutch AVB '96 model policy, for business liability insurance.

${ }^{17}$ e.g. Accountants Professional Liability Insurance.

18 e.g. Lawyers Professional Liability Insurance (Claims Made): see WIDDIS, A., Insurance Materials on Fundamental Principles, Legal Doctrines and Regulatory Acts, American Casebook Series, St. Paul MA, West Publishing Cy, 1989, 577-579.

${ }^{19}$ Section 40 Australian Insurance Contracts Act 1984; see also GRIFFITHS, T., "Time-limits in Claims-made Insurance in Australia and New Zealand", International Insurance Law Review, March 1997, 85-89. 
the match", is much smaller as it is shifted back partly on the back of the insured. If the risk itself, the general knowledge regarding it, the laws on liability and insurance or the claims consciousness really did change for the worse only after the expiration of the policy, then the insured at that time was no less than the insurer unable to assess the importance of notifying this event. Lack of notification entails automatically that this insurer cannot be held to indemnify the harmful consequences of these events. All this means that the insurer can no longer be taken by surprise after many years by totally unexpected claims, unforeseeable and therefore not assessable at the time of the expiration of the policy.

Consequently, the main argument for further limiting the run off period of the circumstances clause has dropped. Moreover, a reasonably "matching" insurance coverage demands an unlimited run off period as the circumstances at the moment of their notification generally have not yet led to any loss. The development process of the liability is only in its initial phase. One can expect, certainly for long tail risks, that loss and claim will only occur a considerable time after the expiration of the policy. Every limitation to the run off period, even if it is still longer than the run off period for the main trigger, would therefore hamper substantially the "effet utile" of a circumstances clause. Adequate coverage can only be "assured" by providing a run off period without limitations ${ }^{20}$.

\section{Prior conditions for a useful functioning of the circumstances clause}

For a useful functioning of the circumstances clause, certain prior conditions must be met. Firstly, much depends on the cautiousness and discipline of the insured. If he fails to notify the first insurer of the circumstances in time, he again loses any coverage. Secondly, it presupposes that both succeeding contracts are based on the same trigger, beit an "act committed", a "loss occurrence" or a "claims made" trigger. The application of different triggers in succeeding contracts creates new gaps in coverage which are hard to fill by a circumstances clause. Thirdly, it is essential that the succeeding insurer covers the complete unknown past of the insured. Once he starts pursuing a strict acceptance policy which to say the least is not unlikely -, again insurance and liability no longer match.

Finally, in the absence of generally accepted guidelines, the "Achilles" heel of a workable circumstances clause is the exact definition of what has to be understood by a "circumstance". The main problem is that a lot will depend on what the insurer understands by it. Effectiveness is affected when both succeeding insurers are interpreting the concept differently. It could be that the notification of an event in the opinion of the first insurer is not to be qualified as a circumstance, since the event cannot be reasonably considered to give rise to a loss or a claim in the future. The second insurer on the other hand could defend that the insured knew of events that have an influence on the assessment of the risk. If they were disclosed before him, he would most likely exclude them from coverage. If not, the insurer can refuse to indemnify on grounds of breach of duty to disclose. Once again the insured and the victim risk falling between the cracks.

20 Such unlimited run off period is provided for in the Dutch AVB ' 96 model policy and in English market practice; Belgium however limits the run off period of the circumstances clause to three years (Article 78, $\$ 2$ Belgian Insurance Contracts Act). 
To fill this gap, an event should at least be considered a "circumstance" as soon as non-disclosure of the possible harmful effect of this event to the new insurer leads to a breach of duty to disclose and consequently to no or less coverage. This way one should get two succeeding insurance contracts that link up with each other imperceptably. The first insurer gives coverage for all circumstances. The second for all other events, since they are not known to the insured in a way that creates a legal duty to disclose ${ }^{21}$. The first insurer can only refuse to recognize the notified event as a circumstance when nondisclosure of this event to the second insurer would not violate the legal duty to disclose. Thus the insured and the victim may rest assured that in any case one of both insurers is obliged to pay for the damages.

When the duty to disclose is interpreted rather narrowly, it is not unlikely that an event can be considered a circumstance, while non-disclosure of this circumstance to the second insurer does not at the same time give rise to a breach of duty. This situation poses no problem at all in terms of adequacy of insurance coverage, on the contrary. In this case there is plurality of insurance coverage, subject to the existence of a contribution clause in one of the insurance contracts.

This linking of the circumstances clause to the duty to disclose is justified by their common grounds of risk assessment. Furthermore, in defining the concept of circumstance one has the comfort of falling back on an existing set of well known rules and elaborate case law concerning the duty to disclose.

The scope of the duty to disclose however can vary substantially between the laws of different countries ${ }^{22}$. The definition of a circumstance will differ accordingly. In countries e.g. where the second insurer can fall back more easily on a breach of duty to disclose, accordingly the first insurer must recognize these events more quickly as "circumstances". Problems may arise when succeeding contracts are governed by different national laws applicable to the insurance contract.

To avoid gaps in coverage, one should apply only one national law concerning the duty to disclose, be it the national law applicable to the first insurance contract or that to the second contract. In practice however insurers can not be obliged to apply a regulation different from the national rule applicable to their insurance contract. There are only two exceptions to this. First, when the national rule could be regarded as a mandatory rule (a so called "loi de police") applicable irrespective of the law otherwise applicable to the insurance contract. This is however not the case since the rules on duty to disclose can not be regarded as protecting a general public interest but intend to ensure an equal balance between the rights and obligations of the parties to a particular contract ${ }^{23}$. Second, under European law, the host Member-State can impose its national rule on a foreign insurer

${ }^{21}$ Supposing that the second insurer accepted to give coverage without reservations for the unknown past.

${ }^{22}$ See C.E.A. Report, E.E.C.-Insurance Contract Law, Paris, May 1990.

${ }^{23}$ DUBUISSON, B.. "Unité ou diversité des notions d'intérêt général, d'ordre public et de normes impératives dans les directives communautaires relatives aux assurances", in L'Europe de l'assurance. Les directives de la troisième génération, CENTRE FOR RISK AND INSURANCE STUDIES and LICENCE EN DROIT ET ECONOMIE DES ASSURANCES (ed.), Brussel, Academia-Bruylant, Antwerpen, Maklu, 1992, p. 221, n 42. 
upon the condition that this national measure "is justified on the grounds of general good". Again, one might expect that the rule concerning the duty to disclose does not apply to these international insurance contracts. At least it seems difficult to sustain that this rule meets the tests developed by the European Court of Justice with respect to national non-discriminatory restrictions to intra-Community trade ${ }^{24}$, and thus "is justified on the grounds of general good".

It is clear that the lack of adequate coverage in case of succeeding contracts governed by a different national law, is a general problem, surpassing the circumstances clause as such. It follows from the lack of harmonisation of the national laws applicable to insurance contracts ${ }^{25}$. Meanwhile the circumstances clause can work in case of succeeding contracts governed by the same national insurance contract law. In our view this will often remain the case - unfortunately even in the Single European Market -, since the risk of substantial gaps in coverage will inhibit the prudent insured largely in concluding a second insurance contract with a different applicable law.

By way of conclusion a more practical solution should be mentioned for the major weakness of the exact definition of the circumstances clause. Dutch insurers and doctrine are at the moment investigating whether differences in conception of the term "circumstance" can be circumvented by closing a convention between all insurers ${ }^{26}$. This convention would contain a.o. the guarantee that one of the two succeeding insurers will always pay. Which one this will be then is a matter to settle between insurers ${ }^{27}$.

${ }^{24}$ See e.g. DUBUISSON, B., l.c., p. 250-260, n 77-88; ROTH, W.H., "Das Allgemeininteresse im Europäischen Internationalen Versicherungsvertragsrecht", Versicherungsrecht, 1993, 129; VAN SCHOUBROECK, C., "The Concept of the General Good", in The Law and Practice of Insurance in the Single European Market, MCGEE, A. and HEUSEL, W. (ed.), Köln, Bundesanzeiger, 1995, 149161.

25 The European Commission's project for a harmonisation of insurance contract law did not succeed (Proposal for a Council Directive on the coordination of laws, regulations and administrative provisions relating to insurance contracts, O.J., $\mathrm{n}^{\circ} \mathrm{C} 190,28 / 7 / 1979,2$; Modified Proposal, O.J., $\mathrm{n}^{\circ} \mathrm{C}$

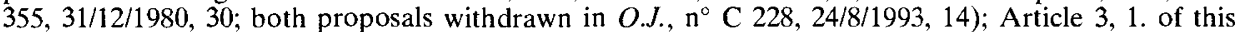
proposal provided the following: "When concluding the contract, the policyholder shall declare to the insurer any circumstances of which he ought reasonably to be aware and which he ought to expect to influence a prudent insurer's assessment or acceptance of the risk. The policyholder shall not be obliged to declare to the insurer circumstances of which the latter is already aware because he has already covered the risk. In the case of a corporate policyholder, circumstances of which it ought reasonably to be aware means circumstances of which the appropriate officer of the corporation ought reasonably to have been aware. Any circumstances in respect of which the insurer has asked specific questions in writing shall, in the absence of proof to the contrary, be regarded as influencing the assessment and acceptance of the risk."

${ }^{26}$ It remains unclear however how insurers will be convinced to adhere all to the convention without exception. Especially foreign insurers who only sell insurance in the Netherlands on the basis of free provision of services or on any other occasional basis, can be expected to stay out of this convention.

27 This however is not entirely true, more particularly when effective coverage for the insured case would be more extensive in one contract than in the other. In that case the choice of the liable insurer has a direct influence on the amount of indemnification. 